\title{
Influence of pre- and post-treatments on formation of a trivalent chromium conversion coating on AA2024 alloy
}

DOI:

10.1016/j.tsf.2016.08.044

\section{Document Version}

Accepted author manuscript

Link to publication record in Manchester Research Explorer

\section{Citation for published version (APA):}

Qi, J., Nmcová, A., Walton, J. R., Zhou, X., Skeldon, P., \& Thompson, G. E. (2016). Influence of pre- and posttreatments on formation of a trivalent chromium conversion coating on AA2024 alloy. Thin Solid Films, 616, 270278. https://doi.org/10.1016/j.tsf.2016.08.044

\section{Published in:}

Thin Solid Films

\section{Citing this paper}

Please note that where the full-text provided on Manchester Research Explorer is the Author Accepted Manuscript or Proof version this may differ from the final Published version. If citing, it is advised that you check and use the publisher's definitive version.

\section{General rights}

Copyright and moral rights for the publications made accessible in the Research Explorer are retained by the authors and/or other copyright owners and it is a condition of accessing publications that users recognise and abide by the legal requirements associated with these rights.

\section{Takedown policy}

If you believe that this document breaches copyright please refer to the University of Manchester's Takedown Procedures [http://man.ac.uk/04Y6Bo] or contact uml.scholarlycommunications@manchester.ac.uk providing relevant details, so we can investigate your claim.

\section{OPEN ACCESS}




\title{
Influence of Pre-and Post-treatments on Formation of a Trivalent Chromium Conversion Coating on AA 2024 Alloy
}

\author{
J. Qi, ${ }^{a}$ A. Němcová, ${ }^{a}$ J.R. Walton, ${ }^{\text {b }}$ X. Zhou, ${ }^{\text {a P. Skeldon }}{ }^{\mathrm{a} *}$ and G.E. Thompson ${ }^{\mathrm{a}}$
}

${ }^{a}$ School of Materials, The University of Manchester, Oxford Rd., Manchester M13 9PL, U.K

${ }^{b}$ TSTC Ltd, 5 Grosvenor Terrace, Teignmouth, TQ14 8NE, UK

*corresponding author

e-mail: p.skeldon@manchester.ac.uk

tel: + 441613064872

fax: + 441613064826 


\section{Abstract}

A comparison has been made of the influence of two alloy pre-treatments and two coating post-treatments on the formation, composition and corrosion protection of a trivalent chromium conversion coating on AA 2024-T351 alloy. The investigation employed analytical electron microscopies, ion beam analysis, X-ray photoelectron spectroscopy (XPS) and electrochemical tests. The pre-treatments used alkaline etching followed by de-oxidizing in either nitric acid or a commercial de-oxidizer. The conversion coatings were formed in SurTec 650 chromitAL and revealed two-layers, comprising an inner aluminium-rich layer and an outer chromium- and zirconium-rich layer, with a $\mathrm{Cr}: \mathrm{Zr}$ atomic ratio in the range $\sim 0.73-0.93$. XPS indicated a chromium-enriched near-surface region that contained $\sim 2$ at. $\%$ of $\mathrm{Cr}$ (VI) species. Potentiodynamic polarization and electrochemical impedance spectroscopy revealed an improved corrosion protection for a pre-treatment that left copperrich sponges, probably de-alloyed $\mathrm{S}$ phase, and fewer residues of other intermetallic particles on the alloy surface. Post-coating immersion treatments in deionized water at $20{ }^{\circ} \mathrm{C}$ or $40{ }^{\circ} \mathrm{C}$ resulted in a significant difference in the zirconium species in the region adjacent to the coating surface that is accessible to XPS, with oxide and hydroxide dominating at the respective temperatures.

Keywords: Aluminium alloy; trivalent chromium conversion coating; corrosion protection; TEM; RBS; XPS

\section{Introduction}


AA2024-T3 aluminium alloy is widely used in the aircraft industry owing to its high strength and damage tolerance. However, the alloy is susceptible to localized corrosion, particularly due to the presence of $\mathrm{CuMgAl}_{2}(\mathrm{~S}), \mathrm{Al}_{2} \mathrm{Cu}(\theta)$ and $\mathrm{Al}-\mathrm{Cu}-\mathrm{Fe}-\mathrm{Mn}-\mathrm{Si}$ intermetallic particles that provide preferred cathodic sites on the alloy surface [1-3]. Chromate conversion coatings are often applied to the alloy in order to confer corrosion protection [4]. However, the toxicity and health concerns relating to $\mathrm{Cr}(\mathrm{VI})$ species have stimulated the development of eco-friendly alternative treatments, including trivalent chromium conversion (TCC) coatings $[5,6]$.

The trivalent chromium bath generally contains zirconium fluorozirconate and trivalent chromium salts [7]. The coating forms by a $\mathrm{pH}$-driven deposition of $\mathrm{Zr}$ - and $\mathrm{Cr}$ - species that follows surface activation by fluoride ions in the coating bath $[6,8,9]$. Studies using the AA 2024 alloy have shown that a coating thickness of $\sim 40$ to $120 \mathrm{~nm}$ is generated under typical conditions of coating growth $[5,10]$. The coating consists of two layers $[5,6,10]$ : an outer layer that contains zirconium and chromium species, with the presence of oxide, hydroxide, fluoride and sulphate species being revealed by XPS [10], and an inner aluminium-rich layer, containing oxygen and fluorine species, possibly representing an oxyfluoride or a mixture of oxide, hydroxide and fluoride $[5,6,10]$. The intermetallic particles influence the coating development, with preferential growth initially taking place above S-phase particles $[8,10]$. Furthermore, cracks may be formed in the coating in the vicinity of the particles. In addition, localized corrosion of AA 2024 alloy has been reported to occur at the base of the coating, which appears to be associated with the enrichment of copper in the alloy matrix and enhanced concentrations of fluoride ions in the inner coating layer that develop during the coating process $[10]$. 
In view of the detrimental influences of the intermetallic particles on the uniformity of coatings and hence to the corrosion protection, the selection of a surface pre-treatment is an important consideration [11, 12]. For instance, it has been reported that the corrosion protection by a TCC coating was reduced by prolonged use of an acidic fluoride deoxidizer [13]. In contrast, another study found no significant difference in the coating formation following two different alkaline etching and deoxidizing pre-treatments [6]. In the present study, the effects of two different pre-treatments of AA2024-T351 alloy on the formation of a TCC coating in a SurTec 650 chromitAL bath are investigated using high-resolution, analytical electron microscopies, ion beam analysis and XPS. Furthermore, the effects on the coating chemistry of two different post-coating treatments are determined. The electrochemical behaviour and corrosion protection are assessed by cyclic voltammetry, potentiodynamic polarization and electrochemical impedance spectroscopy.

\section{Experimental Details}

\subsection{Materials and treatment}

AA2024-T351 aluminium alloy panels (1.5 mm thick) were cut to dimensions of $30 \times 24 \mathrm{~mm}$ or $30 \times 12 \mathrm{~mm}$. They were then cleaned by immersion for $5 \mathrm{~s}$ in acetone, ethanol and deionized water, and mechanically polished using SiC papers to a 4000 finish. Two chemical pre-treatments were then employed: (i) etching for $60 \mathrm{~s}$ in $5 \mathrm{wt} . \%$ sodium hydroxide solution at $60{ }^{\circ} \mathrm{C}$ and de-oxidizing for $30 \mathrm{~s}$ in 50 vol. \% nitric acid $(70 \%)$ at $25{ }^{\circ} \mathrm{C}$ (designated pretreatment 1); (ii) etching for $30 \mathrm{~s}$ in $10 \mathrm{wt} . \%$ sodium hydroxide at $60^{\circ} \mathrm{C}$ and de-oxidizing for $90 \mathrm{~s}$ in 15 vol. \% Oxidite D-30 (MacDermid) solution at $30^{\circ} \mathrm{C}$ (designated pre-treatment 2). Specimens were then rinsed in deionized water and dried in a cool air stream. 
Conversion coating was carried out by immersion in $20 \mathrm{v} / \mathrm{v} \%$ SurTec 650 chromitAL (SurTec Corp., UK) solution at $40{ }^{\circ} \mathrm{C}$ for times from 5 to $600 \mathrm{~s}$, with the $\mathrm{pH}$ adjusted to 3.9 by addition of 1 wt.\% $\mathrm{NaOH}$ solution. Inductively-coupled plasma-optical emission spectroscopy, using a Perkin-Elmer Optima 5300 dual view instrument, revealed a $\mathrm{Cr}: \mathrm{Zr}$ atomic ratio of $\sim 0.70 \pm 0.01$ in the bath. Analytical grade chemicals and deionized water with a $\mathrm{pH}$ of 5.8 and resistivity of $18 \mathrm{M} \Omega \mathrm{cm}$ were used to prepare all solutions. A post-treatment immersion in deionized water at either 20 or $40{ }^{\circ} \mathrm{C}$ for $120 \mathrm{~s}$ was then applied, followed by rinsing in deionized water and drying in a cool air stream. Post-treatment in deionized water has been reported to be important for stabilizing the fresh coating [5]. Except for specimens investigated by ion beam analysis, the coated specimens were stored for $24 \mathrm{~h}$ in the laboratory air before surface examination or corrosion testing. The former specimens were analysed one week after forming the coating.

\subsection{Characterization techniques}

The coatings were examined by scanning electron microscopy (SEM), using a Zeiss Ultra 55 FEG SEM instrument (accelerating voltages of 3 or $15 \mathrm{kV}$ ) and associated energy dispersive X-ray (EDX) spectroscopy. Specimen cross-sections for transmission electron microscopy (TEM) were prepared on a LEICA EM UC6 ultramicrotome using a diamond knife. The slices, nominally $30 \mathrm{~nm}$ thick, were collected on nickel grids and examined using a JEOL 2000 FX II microscope at an accelerating voltage of $120 \mathrm{kV}$.

Rutherford backscattering spectroscopy (RBS) was employed to determine the compositions of coatings, using ion beams provided by the Van de Graaff generator at the University of 
Namur, Belgium; $2 \mathrm{MeV}{ }^{4} \mathrm{He}^{+}$ions were incident normal to the specimen surface, with scattered ions detected at $165^{\circ}$ to the direction of the incident beam of $\sim 1 \mathrm{~mm}$ diameter. The data were interpreted using XRUMP software.

The chemical states of coating species were determined by X-ray photoelectron spectroscopy (XPS), using an Axis Ultra DLD spectrometer (Kratos Analytical, Manchester, U.K.) with monochromatic $\mathrm{Al} \mathrm{K} \alpha$ radiation $(\mathrm{h} v=1486.6 \mathrm{eV})$ and a base pressure of $1.0 \times 10^{-6} \mathrm{~Pa}$. The area of the XPS analysis was $\sim 700 \times 300 \mu \mathrm{m}$. CasaXPS version 2.3.17 (Casa Software, Teignmouth, UK) was used to analyse data. Charge referencing was carried out with respect to the $\mathrm{C} 1 \mathrm{~s}$ hydrocarbon peak at $285.0 \mathrm{eV}$ binding energy. The quantified data were corrected for attenuation in the contamination overlayer, following determination of its thickness using the Tougard non-interactive peak shape method [14], so that the concentrations of elements with widely different kinetic energies, for example chromium and sulphur and zirconium and fluoride, can be compared.

Peak fitting of sulphate and fluoride species was then constrained to ensure that the concentration of these compounds did not exceed their elemental concentrations.

\subsection{Electrochemical measurements}

A three-electrode cell was used for all electrochemical measurements, with a Solarton electrochemical workstation and Modulab software controller. The cell contained a saturated calomel reference electrode $\left(\mathrm{SCE}, 4 \mathrm{M} \mathrm{KCl}, \mathrm{E}^{\circ}=0.241 \mathrm{~V}\right.$ vs $\left.\mathrm{SHE}\right)$, a platinum wire counter electrode and a working electrode with an exposed area of $2.25 \mathrm{~cm}^{2}$. The open circuit potential (OCP) in the SurTec 650 chromitAL solution at $40^{\circ} \mathrm{C}$ was measured for times up to 600 s. Electrochemical impedance spectroscopy (EIS) and potentiodynamic polarization 
measurements in naturally aerated $0.05 \mathrm{M} \mathrm{NaCl}$ solution at room temperature were carried out on specimens coated for $300 \mathrm{~s}$. The specimens were first exposed to the solution for 30 min. Measurements were repeated three times for both electrochemical methods. EIS measurements were made in the frequency range $10^{5}$ to $10^{-2} \mathrm{~Hz}$, with a potential amplitude of $10 \mathrm{mV}$ about the OCP. ZView software (version 3.1, Scribner Associates, Inc.) was used to fit the experimental EIS data. Potentiodynamic polarization was carried out from $-1.0 \mathrm{~V}_{\mathrm{SCE}}$ to $1.0 \mathrm{~V}_{\mathrm{SCE}}$ at a rate of $1 \mathrm{mV} / \mathrm{s}$.

The relative amounts of electroactive copper on the surfaces of the pre-treated alloys were determined by cyclic voltammetry $(\mathrm{CV})$ in a saturated borate buffer solution of $\mathrm{pH} 8.4$, consisting of $8.17 \mathrm{~g} / \mathrm{l}$ sodium borate $\left(\mathrm{Na}_{2} \mathrm{~B}_{4} \mathrm{O}_{7} \cdot 10 \mathrm{H}_{2} \mathrm{O}\right)$ and $7.07 \mathrm{~g} / \mathrm{l}$ boric acid $\left(\mathrm{H}_{3} \mathrm{BO}_{3}\right)$, as described elsewhere $[15,16]$. The solution was deaerated for 30 min with nitrogen. The tests consisted of (i) a 5 min hold at a constant potential of $-0.7 \mathrm{~V}_{\mathrm{SCE}}$; (ii) a scan from $-0.7 \mathrm{~V}_{\mathrm{SCE}}$ to $0.3 \mathrm{~V}_{\mathrm{SCE}}$, then back to $-1.2 \mathrm{~V}_{\mathrm{SCE}}$, at a rate of $1 \mathrm{mV} / \mathrm{s}$; (iii) a $10 \mathrm{~min}$ hold at $-0.7 \mathrm{~V}_{\mathrm{SCE}}$; (iv) a repeat of step (ii); (v) a 20 min hold at $-0.7 \mathrm{~V}_{\mathrm{SCE}}$; and (vi) a repeat of step (ii). The heights of the $\mathrm{Cu}(0) / \mathrm{Cu}(\mathrm{I})$ peak in the last scan, i.e. in step (vi), were used to determine the relative amounts of electroactive copper $[15,16]$.

\section{Results and discussion}

\subsection{Surface condition of the pre-treated alloy}

Figure 1 shows scanning electron micrographs of the pre-treated alloy surfaces. Following both pre-treatments, the surfaces contained numerous cavities, which were originally the locations of intermetallic particles that have been either dissolved or dislodged. Grain 
boundaries are also revealed and occasional intermetallic particles that have undergone either little or partial dissolution. The intermetallic residual particles were more numerous following pre-treatment 1; EDX analysis identified $\theta$ - and S-phase (Fig. 2 (a), labelled 1 and 2, respectively) and $\mathrm{Al}-\mathrm{Cu}-\mathrm{Fe}-\mathrm{Mn}-\mathrm{Si}$ particles (Fig. 2 (b), labelled 3). Typical analyses are presented in Table 1 . The copper contents, $\sim 53,42$, and $21 \mathrm{wt} . \%$, and the presence of $14 \mathrm{wt} . \%$ magnesium in the S phase particle, suggest that only small changes in the compositions of the residual intermetallic particles had occurred due to the pre-treatment. The low concentration of oxygen detected by the EDX analysis is mainly due to the oxide/hydroxide films on the particle surfaces. Following pre-treatment 2, relatively large, copper-rich sponges (see arrows in Fig. 1 (b)), of size up to $\sim 40 \mu \mathrm{m}$, probably formed by de-alloying of $\mathrm{S}$ phase particles [3, 17], were the most significant surface features. These were not observed following pretreatment 1 . Other intermetallic remnants were only a few microns in size compared with up to $20 \mu \mathrm{m}$ after pre-treatment 1 ; furthermore, cavities were more numerous and grooves from mechanical polishing were fainter in comparison with pre-treatment 1 . Grain boundaries were also clearly revealed by pre-treatment 2 . An example of a copper-rich sponge, which contained $>90 \% \mathrm{Cu}$, according to EDX analysis, is shown in Fig. 2(c) (labelled 4). Later potentiodynamic polarization measurements indicate a substantial reduction in the number of cathodic sites on the alloy surface following pre-treatment 2 due to the increased removal of intermetallic particles compared with pre-treatment 1 . In the case of pre-treatment $2, \mathrm{Fe}(\mathrm{III})$, which is a constituent of the de-oxidizing solution, may play a role in the dissolution of aluminium and copper $[18,19]$, according to the reactions:

$$
\begin{gathered}
3 \mathrm{Fe}^{3+}+\mathrm{Al} \rightarrow 3 \mathrm{Fe}^{2+}+\mathrm{Al}^{3+} \\
2 \mathrm{Fe}^{3+}+\mathrm{Cu} \rightarrow 2 \mathrm{Fe}^{2+}+\mathrm{Cu}^{2+}
\end{gathered}
$$


Figure 3 shows the results of $\mathrm{CV}$ measurements in the deaerated borate buffer solution for the alloy in the mechanically-polished condition and also following pre-treatments 1 and 2. The height of the $\mathrm{Cu}(0) / \mathrm{Cu}(\mathrm{I})$ oxidation peak at $-0.14 \mathrm{~V}_{\mathrm{SCE}}$ was greatest for pre-treatment $2, \sim 1.7$ $\mu \mathrm{A} / \mathrm{cm}^{2}$, compared with $\sim 0.2 \mu \mathrm{A} / \mathrm{cm}^{2}$ for the mechanically polished condition and following pre-treatment 1 . Thus, pre-treatment 2 led to almost an order of magnitude greater amount of electroactive copper compared with pre-treatment 1 . Davenport et al. used $\mathrm{Al}-0.2 \mathrm{wt} \% \mathrm{Cu}$ and Al- $1 \mathrm{wt} \% \mathrm{Cu}$ model alloys treated in nitric acid to simulate the behaviour of the AA 2024 matrix and found no electroactive copper using a similar CV procedure [20]. Hence, the copper of the present measurements is probably associated with the residues of intermetallic particles. The electroactive copper may encourage the initial deposition of chromium and zirconium species. Of relevance to this possibility, a correlation between the presence of a zirconium-rich deposit and copper either in the solution [21] or in the substrate [22] has been reported, and preferential formation of a zirconium-rich coating has been observed on $\mathrm{S}$ phase in earlier work of the present authors [10]. Any effect of the electroactive copper may be limited to the early stages of coating growth before it is covered by the growing coating.

RBS examination of the specimens following pre-treatments 1 and 2 revealed similar spectra, with the main feature of interest being a peak from copper that is enriched in the alloy immediately beneath the oxide/hydroxide film on the alloy surface. Figure 4 shows the spectrum for a specimen following pre-treatment 2 as an example of a measured spectrum. The solid line shows the fitted spectrum. A small peak due to oxygen in the oxide/hydroxide film on the alloy surface is superimposed on the yield from aluminium in the alloy. From previous studies of etched and desmutted $\mathrm{Al}-\mathrm{Cu}$ alloys [23], it is well-established that the copper enriched layer is $\sim 2 \mathrm{~nm}$ thick. The copper peaks in the spectra corresponded to similar 
enrichments of $\sim 6 \times 10^{15}$ copper atoms $/ \mathrm{cm}^{2}$ following the two pre-treatments, which is similar to the amounts found in earlier measurements on Al-Cu alloys [23]. The enrichment is related to the relative nobility of copper and reaches an approximately constant level during etching.

\subsection{Coating formation and composition}

Figure 5 shows the OCPs of specimens with pre-treatments 1 and 2 during immersion in the SurTec 650 chromitAL bath at $40{ }^{\circ} \mathrm{C}$ for $600 \mathrm{~s}$. The potentials initially fall to minimum values of -1.00 and $-1.07 \mathrm{~V}_{\mathrm{SCE}}$, respectively, at times of $\sim 50$ and $20 \mathrm{~s}$, with a shoulder evident for pre-treatment 1 . The decrease in potential is probably due to the deposition of coating on the residual intermetallic particles, which reduces the availability of cathodic sites for the oxygen reduction or hydrogen evolution reactions. During the subsequent times of treatment, the potentials gradually rise toward values of -0.86 and $-0.93 \mathrm{~V}_{\mathrm{SCE}}$ following pre-treatments 1 and 2, respectively.

Transmission electron micrographs of ultramicrotomed cross-sections of the TCC coatings on the alloy matrix after pre-treatment 2 and immersion in the SurTec 650 chromitAL bath for 15,60 and $300 \mathrm{~s}$, followed by post-treatment immersion in deionized water at $40{ }^{\circ} \mathrm{C}$, are presented in Figs. 6 (a - c), respectively, revealing coating thicknesses of $\sim 21,28$ and $48 \mathrm{~nm}$. The relatively dark region of the coatings contains chromium and zirconium species that increase the electron scattering. The patches of lighter material at the coating surfaces consist of resin that was used in preparing the cross-sections. The thin layers of light appearance at the base of the coatings are aluminium-rich, probably consisting mainly of a mixture oxide, hydroxide and fluoride species [6,10]. A dark band in the alloy at the coating base is associated with the copper enrichment, which is confirmed by later RBS. The band appears 
discontinuous due its thinness relative to the thickness of the TEM section. The presence of an aluminium-rich layer located above the chromium- and zirconium-containing layer was observed in a previous study of a TCC coating formed for $60 \mathrm{~s}$; which was considered to be a transient layer, since it was not seen at other times [10]. Such a layer was not observed in the present cross-sections. The cross-sections of coatings following pre-treatment 1 were similar to the ones formed following pre-treatment 2 and hence are not shown. However, small regions of localized corrosion of the substrate beneath the coating were commonly observed, which has been reported previously for pre-treatment 1 , but with a post-treatment in deionized water at $20{ }^{\circ} \mathrm{C}[10]$. Hence, such localized corrosion was not significantly affected by the temperature of the post-treatment. However, similar localized corrosion was only very occasionally evident in the sections examined following pre-treatment 2 and post-treatment at $40^{\circ} \mathrm{C}$ suggesting it was much reduced in extent. The reason for the difference in the localized corrosion with the two pre-treatments is uncertain.

The dependence of the coating thickness above the alloy matrix, determined by TEM, on the immersion time in the TCC bath is shown in Fig. 7 for the two pre-treatments. The measured coating thicknesses for pre-treatment 2 in the first $100 \mathrm{~s}$ were greater than those of coatings formed following pre-treatment 1 . The thicknesses after the longer times were similar for the two pre-treatments; the final thickness at $600 \mathrm{~s}$ was about $75 \mathrm{~nm}$. Earlier work using pretreatment 1 has shown that the temperature of the post-treatment has only a very minor influence on the coating thickness [24]. The thicknesses measured by TEM may differ from the thicknesses of the freshly formed coatings due to coating shrinkage on dehydration in the ambient laboratory environment and during exposure to the vacuum and the electron beam in the microscope. Furthermore, a very small region of the specimen is examined by TEM and 
local variations in the coating thickness may occur across the coated area, for instance due to influences of preferred cathodic sites on deposition of the coating material.

Figure 8 compares the experimental RBS data for specimens coated for $300 \mathrm{~s}$ following pretreatments 1 and 2 (presented in black and red, respectively), with a post-treatment in deionized water at $40{ }^{\circ} \mathrm{C}$, showing peaks for oxygen, fluorine, sulphur, chromium, zirconium and hafnium in the coatings. RBS cannot detect hydrogen, which may be present in the coating as hydroxide or bound water. Hafnium is an impurity associated with zirconium; the atomic ratio of $\mathrm{Hf}: \mathrm{Zr}$ in the coatings was $\sim 0.01$. The yields from sulphur, fluorine and oxygen are low and superimposed on the yield from either aluminium or heavier elements in the alloy, which prevented the quantification of former elements with high accuracy. Hence, the analyses focused on measuring the amounts of chromium and zirconium, which produced well-resolved yields. The individual chromium and zirconium contents were measured to an accuracy of about $10 \%$. Table 2 shows the results determined from fitting of the RBS data; it also includes measurements for specimens coated for $60 \mathrm{~s}$. The atomic ratios of $\mathrm{Cr}: \mathrm{Zr}$ ranged from 0.73 to 0.93 , the lower end of the range being close to the ratio of these elements measured in the TCC bath. The Cr:Zr ratios are greater than found previously, when a ratio of $\sim 0.5$ was determined by RBS [10]. The main difference between the experiments was the source of the SurTec 650, which, in the former study, was an aircraft manufacturer and, in the present study, the SurTec company, and the temperature of the post-treatment in deionized water, which was $40{ }^{\circ} \mathrm{C}$ in the present work and $20{ }^{\circ} \mathrm{C}$ in the previous study. The leading edges of the aluminium yield for the specimen coated following pre-treatment 1 is shifted to a lower energy compared with the specimen coated following pre-treatment 2 , suggesting that the coating on the former specimens is thicker or has a higher density. The combined total of zirconium and chromium in the coating formed for $60 \mathrm{~s}$ was about $20 \%$ higher for pre- 
treatment 2 compared with pre-treatment 1, but $25 \%$ lower after coating for $300 \mathrm{~s}$. The coating thicknesses determined by TEM, shown in Fig. 7, indicate a greater thickness of the coating formed for $60 \mathrm{~s}$ following pre-treatment 2 in comparison with pre-treatment 1 , which coincides with the trend the zirconium and chromium contents determined by RBS. However, the coatings formed for $300 \mathrm{~s}$ were of similar thickness following the two pre-treatments, whereas a lower amount of zirconium and chromium was measured by RBS for pre-treatment 2. As noted earlier, differences in coating thickness may arise from variations across the specimen surface. In this respect, RBS examines a large area of the surface compared with TEM. Furthermore, the assessment of the relative thickness of the coatings from the RBS analysis of the zirconium and chromium contents excludes consideration of the inner, aluminium-rich region, which was measured by TEM.

The copper peaks in the RBS spectra arise from copper enrichment beneath the conversion coating that was evident in the transmission electron micrographs of Fig. 6. The presence of the copper enrichment has also been demonstrated in previous work using EDX spectroscopy [10]. The enrichments appear similar to the amounts that existed following the pre-treatments only, accurate values being difficult to measure due to the non-uniformity of the coating thickness, the roughness of the alloy/coating interface and the incorporation of copper species into the coating. The $\mathrm{Cu}: \mathrm{Zr}$ atomic ratio in the coatings formed for $300 \mathrm{~s}$ was $\sim 0.1$.

The elemental concentrations determined by XPS from the wide scan spectra of the coatings formed for $300 \mathrm{~s}$ following pre-treatments 1 and 2 are shown in Table 3. The Cr: $\mathrm{Zr}$ ratios were 1.16 and 1.23 for pre-treatments 1 and 2 respectively. The higher values determined by XPS compared with RBS are possibly due to the difference in the depths of the analysis of the two techniques, with XPS analysing the outer $\sim 5 \mathrm{~nm}$ of the coating thickness, while RBS 
analyses the whole of the coating thickness, or to compositional variations across the specimen surface. Figures $9(\mathrm{a}, \mathrm{b})$ show the high-energy-resolution spectra for the $\mathrm{Cr} 2 \mathrm{p}_{3 / 2}$ (Fig. 9a) and the Zr 3d (Fig. 9b) photoelectron regions for a specimen treated in the TCC bath for $300 \mathrm{~s}$, with pre-treatment 2 and post-treatment in deionized water at $40{ }^{\circ} \mathrm{C}$. Analyses of aluminium and copper were not attempted due to the low signal intensities and interference from other species $[25,26]$. Four peaks were used to fit the $\mathrm{Cr} 2 \mathrm{p}_{3 / 2}$ photoelectron region: $\mathrm{Cr}(\mathrm{OH})_{3}(577.9 \mathrm{eV}, 56.3 \%), \mathrm{Cr}_{2}\left(\mathrm{SO}_{4}\right)_{3}(578.6 \mathrm{eV}, 10.5 \%), \mathrm{Cr}(\mathrm{VI})$ species $\left(579.3 \mathrm{eV}, \mathrm{CrO}_{3}\right.$, $\mathrm{CrO}_{4}{ }^{2-}$ or $\left.\mathrm{Cr}_{2} \mathrm{O}_{7}^{2-}, 16.6 \%\right)$, and $\mathrm{CrF}_{3}(580.2 \mathrm{eV}, 16.6 \%)[27,28]$; the percentages are expressed with respect to the total area of the $\mathrm{Cr} 2 \mathrm{p}_{3 / 2}$ region. Fitting of the $\mathrm{Cr} 2 \mathrm{p}_{3 / 2}$ peak for a coating formed for $300 \mathrm{~s}$ following pre-treatment 1 was achieved using the same component species, namely $\mathrm{Cr}(\mathrm{OH})_{3}(59.7 \%), \mathrm{Cr}_{2}\left(\mathrm{SO}_{4}\right)_{3}(20.1 \%)$, $\mathrm{Cr}(\mathrm{VI})$ species (12.7\%), and $\mathrm{CrF}_{3}$ (7.5\%), with $\mathrm{Cr}(\mathrm{OH})_{3}$ again being the dominant chromium species. The reduction in the percentages of sulphate species is due to the constraint determined from the elemental concentrations, not the accuracy of the peak fitting. The values being compared here are relative intensities. The absolute intensities for the sulphate species are 1.1 and 2.1 at $\%$. Note the elemental concentrations of the S $2 \mathrm{p}$ are 1.4 and 1.2 at\% (Table 3), and it is this uncertainty which is the limiting factor.

The $\mathrm{Zr} 3 \mathrm{~d}$ photoelectron region was fitted using the presence of $\mathrm{ZrF}_{4}, \mathrm{Zr}(\mathrm{OH})_{4}$ and $\mathrm{ZrO}_{2}$, with the respective $\mathrm{Zr} 3 \mathrm{~d}_{3 / 2}$ and $\mathrm{Zr} 3 \mathrm{~d}_{5 / 2}$ peaks at binding energies of 186.9 and $184.5 \mathrm{eV}$ for $\mathrm{ZrF}_{4}, 186.4$ and $184.0 \mathrm{eV}$ for $\mathrm{Zr}(\mathrm{OH})_{4}$ and 185.3 and $182.9 \mathrm{eV}$ for $\mathrm{ZrO}_{2}$ [29]. About 60.3\%, $30.4 \%$ and $9.3 \%$ of the zirconium were in the form of hydroxide, oxide and fluoride, respectively. The $\mathrm{Zr} 3 \mathrm{~d}$ photoelectron region for a specimen conversion coated following pretreatment 1 could be fitted using the same components with about $46.4 \%, 36.5 \%$ and $17.1 \%$ of the zirconium being present as hydroxide, oxide and fluoride, respectively (Fig. 9 (c)). In 
contrast, after pre-treatment 2 and a post-treatment at $20{ }^{\circ} \mathrm{C}$ rather than $40{ }^{\circ} \mathrm{C}$, the fitting was achieved with $\mathrm{ZrO}_{2}(96.2 \%)$ and a small amount of fluoride (3.8\%) (Fig. 9 (d)). This agrees with the result of a previous XPS analysis of specimen using pre-treatment 1 and a posttreatment at $20{ }^{\circ} \mathrm{C}$ [10]. Thus, the results indicate that the increased temperature of the posttreatment causes a partial transformation of the zirconium oxide species into zirconiumhydroxide species in the outer $\sim 5 \mathrm{~nm}$ of the coating thickness. The zirconium hydroxide species are possibly located in thin layer adjacent to the coating surface, with oxide species being detected from the underlying material. In contrast, the hydroxide associated with chromium is less significantly affected by the post-treatment temperature.

The concentration of the $\mathrm{Cr}(\mathrm{VI})$ species measured by XPS in the coating formed for $300 \mathrm{~s}$ following pre-treatment $2(\sim 1.9$ at.\%) was greater than that for pre-treatment $1(1.1$ at.\% $\mathrm{Cr}(\mathrm{VI})$ ), although this difference is not considered significant. Furthermore, the depth of analysis of XPS is limited to the outer $\sim 5 \mathrm{~nm}$ of the coating thickness. The $\mathrm{Cr}(\mathrm{VI})$ may form either during the coating growth or subsequent storage due to oxidation $\mathrm{Cr}$ (III) species by $\mathrm{H}_{2} \mathrm{O}_{2}$, generated by the reduction of oxygen [30]. During coating formation, the OCP of the alloy is above the standard equilibrium potential of around $-1.3 \mathrm{~V}_{\mathrm{SCE}}$ for the $\mathrm{O}_{2} / \mathrm{H}_{2} \mathrm{O}_{2}$ reaction [31]. In addition, the presence of copper sponges may promote the generation of hydrogen peroxide, as reported by $\mathrm{Li}$ et al., who revealed the local presence of hexavalent chromium around coated copper-rich particles after air ageing [30]. The Cr(VI) species can enhance the corrosion protection provided by the coatings [4].

\subsection{Electrochemical Properties}


EIS measurements of specimens subjected to pre-treatments 1 or 2 , then coated for $300 \mathrm{~s}$ and post-treated in deionized water at $40{ }^{\circ} \mathrm{C}$ were carried out in naturally aerated $0.05 \mathrm{M} \mathrm{NaCl}$ solution. The OCPs of the coated alloys before the EIS measurements were carried out were $\sim-0.53$ and $-0.55 \mathrm{~V}$ vs. SCE after pre-treatment 1 and pre-treatment 2, respectively. At such potentials, oxygen reduction is expected to be the dominant cathodic reaction that accompanies the oxidation of the alloy. The relationships of the impedance modulus and the phase angle to the frequency are shown in Figs $10(\mathrm{a}, \mathrm{b})$, respectively. The equivalent circuit used to fit the data is illustrated in Fig. 11 [32-34], where constant phase elements (CPEs) were used to replace capacitances. The impedance of the CPE is given by $(j \omega)^{-n} Q^{-1}$, where a larger value of $n$ indicates greater homogeneity of the TCC coating [29]. The effective capacitance of the CPE is given by $\mathrm{Q}^{1 / n} \mathrm{R}^{(1-\mathrm{n}) / \mathrm{n}}$, where $\mathrm{R}$ is the electrolyte resistance [29]. The results of the fitting are shown in Table 4 , where $\chi^{2}$ errors were $<10^{-3}$.

The resistance due to the coating, $\mathrm{R}_{\text {coat }}$, is determined mainly by the influence of defects in the coating, such as pores and cracks [33]; the value $\mathrm{R}_{\text {coat }}$ for the specimen with pre-treatment 2 was over an order of magnitude greater than that for the specimen with pre-treatment 1 . The charge-transfer resistances, $R_{p}$, were also greater by a factor of $\sim 3$. The effective capacitances,

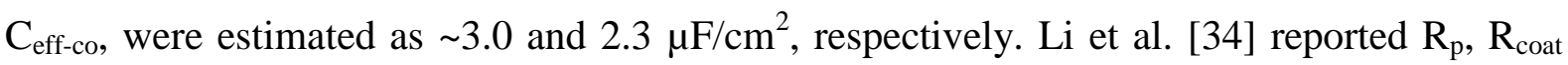
and $\mathrm{C}_{\text {eff }}$ values of $3.3 \times 10^{5} \Omega \mathrm{cm}^{2}, 525 \Omega \mathrm{cm}^{2}$ and $\mathrm{C}_{\mathrm{eff}}=2.49 \mu \mathrm{F} / \mathrm{cm}^{2}$ for a TCC coating formed on AA2024 alloy for $600 \mathrm{~s}$, but using a different pre-treatment of the alloy and a different commercial TCC bath from those of the present study. $\mathrm{R}_{\text {coat }}$ and $\mathrm{C}_{\text {eff }}$ are of a similar order as the values for the present specimens coated following pre-treatment 1 , although the latter specimens revealed a significantly lower $R_{p}$. The higher $R_{\text {coat }}$ of the specimens coated following pre-treatment 2 compared those coated following pre-treatment 1 suggests the presence of a reduced number of defects, such as cracks or pores, in the coatings on the 
former specimens. Cracks may form owing to the stresses generated by differences in the rates of coating growth above the matrix and residual intermetallic particles and shrinkage of the coating as it dries in the laboratory atmosphere.

Figure 12 shows the potentiodynamic polarization curves in naturally aerated $0.05 \mathrm{M} \mathrm{NaCl}$ solution for bare and coated specimens subjected to pre-treatments 1 and 2 . The cathodic current was reduced for the bare alloy by pre-treatment 2 in comparison with pre-treatment 1 and further reduced following application of the coating. The reduction in the cathodic activity by the coating is consistent with other reports $[1,33]$. At $-0.75 \mathrm{~V}_{\mathrm{SCE}}$, the cathodic current densities for coated specimens de-oxidized in nitric acid were $\sim 1 \times 10^{-6}$ and $1 \times 10^{-7}$ $\mathrm{A} / \mathrm{cm}^{2}$ with pre-treatments 1 and 2, respectively. Physical blocking by the TCC coatings reduces the oxygen availability near the substrate, resulting in the cathodic inhibition; pretreatment 2 that resulted in copper-rich sponges and a smaller number of other residual intermetallic particles on the alloy surface provided the greatest corrosion protection. However, the similarity of the pitting potentials for the bare and coated specimens indicates that the barrier property of the coatings is insufficient to prevent chloride ions reaching the alloy and that the amounts of hexavalent chromium species in the coatings are too low to provide significant anodic inhibition.

\section{Conclusions}

The TCC coatings formed on the AA2024-T351 alloy consists of an inner aluminium-rich layer and an outer chromium- and zirconium-rich layer. The average atomic ratio of

chromium to zirconium in the outer layer is in the range 0.73 to 0.93 . XPS indicated a chromium-enriched surface region that contained $\sim 2$ at.\% $\mathrm{Cr}(\mathrm{VI})$ species. Electrochemical 
measurements indicate that the pre-treatments have a major influence on the corrosion protection of the alloy provided by the $\mathrm{TCC}$ coating in $\mathrm{NaCl}$ solution. A pre-treatment that used a commercial deoxidizer left copper-rich sponges, probably de-alloyed $\mathrm{S}$ phase, and fewer residues of other intermetallic particles compared with de-oxidation in nitric acid resulted in a coating with improved barrier protection. The pre-treatment affects the enrichment of copper in the alloy matrix, the amount of electroactive copper on the alloy surface and the composition of residual second intermetallic particles. A much greater amount of electroactive copper was present following the pre-treatment with the commercial de-oxidizer that was probably related to the presence of copper-rich sponges formed by dealloying of S phase particles. The temperature of a post-treatment of the coated specimens by immersion in deionized water has a significant effect chemical state of the zirconium in the surface region of the coating. Immersion at $40^{\circ} \mathrm{C}$ results in the presence of zirconium hydroxide as the major species. In contrast, mainly oxide species are present following immersion at $20{ }^{\circ} \mathrm{C}$. The temperature of the post-treatment has a less significant effect on the amount of hydroxide associated with chromium.

\section{Acknowledgements}

EPSRC is acknowledged for support of the LATEST 2 Programme Grant (grant no. H020047/1) and the China Council Scholarship for support of J. Qi. The technical assistance of Mr Paul Lythgoe in ICP-AES analyses of SurTec 650 chromitAL is also greatly appreciated. The European Community is also thanked for financial support within the Integrating Activity "Support of Public and Industrial Research Using Ion Beam Technology (SPIRIT)", under EC contract no. 227012. 


\section{References}

[1] G.S. Chen, M. Gao, R.P. Wei, Microconstituent-induced pitting corrosion in aluminum alloy 2024-T3, Corrosion 52 (1996) 8-15.

[2] A. Boag, A.E. Hughes, N.C. Wilson, A. Torpy, C.M. MacRae, A.M. Glenn, T.H. Muster, How complex is the microstructure of AA2024-T3?, Corros. Sci. 51 (2009) $1565-1568$.

[3] T. Hashimoto, X. Zhang, X. Zhou, P. Skeldon, S.J. Haigh, G.E. Thompson, Investigation of dealloying of $\mathrm{S}$ phase $\left(\mathrm{Al}_{2} \mathrm{CuMg}\right)$ in $\mathrm{AA} 2024-\mathrm{T} 3$ aluminium alloy using high resolution 2D and 3D electron imaging, Corros. Sci. (2015) 157-164.

[4] M.W. Kendig, R.G. Buchheit, Corrosion inhibition of aluminum and aluminum alloys by soluble chromates, chromate coatings, and chromate-free coatings, Corrosion 59 (2003) 379-400.

[5] L.L. Li, G.P. Swain, A. Howell, D. Woodbury, G.M. Swain, The formation, structure, electrochemical properties and stability of trivalent chrome process (TCP) coatings on AA2024, J. Electrochem. Soc. 158 (2011) C274-C283.

[6] Y. Guo, G.S. Frankel, Characterization of trivalent chromium process coating on AA2024-T3, Surf. Coat. Technol. 206 (2012) 3895-3902.

[7] F. Pearistein, V.S. Agarwala, Trivalent chromium solutions for applying chemical conversion coatings to aluminium alloys or for sealing anodied aluminium, Plat. Surf. Finish. 81 (1994) 50-55.

[8] A. Sarfraz, R. Posner, M.M. Lange, K. Lill, A. Erbe, Role of second phases and copper in the deposition of $\mathrm{ZrO}_{2}$ conversion coatings on AA6014, J. Electrochem. Soc. 161 (2014) C509-C516.

[9] L. Li, A. L. Desouza, G.M. Swain, In situ $\mathrm{pH}$ measurement during the formation of conversion coatings on an aluminum alloy (AA2024), Analyst 138 (2013) 4398-4402.

[10] J. Qi, T. Hashimoto, J. Walton, X. Zhou, P. Skeldon, G.E. Thompson, Formation of a trivalent chromium conversion coating on AA2024-T351 Alloy, J. Electrochem. Soc. 163 (2016) C25-C35. 
[11] P. Campestrini, H. Terryn, A. Hovestad, J.H.W. de Wit, Formation of a cerium-based conversion coating on AA2024: relationship with the microstructure, Surf. Coat. Technol. 176 (2004) 365-381.

[12] Z. Feng, Y. Liu, T. Hashimoto, G.E. Thompson, X. Zhou, P. Skeldon, Influence of surface pretreatments on the corrosion protection of sol-gel coated AA2024-T3 aluminium alloy, Surf. Interface Anal. 45 (2013) 1452-1456.

[13] L. Li, A. L. Desouza, G.M. Swain, Effect of Deoxidation Pretreatment on the Corrosion Inhibition Provided by a Trivalent Chromium Process (TCP) Conversion Coating on AA2024-T3, J. Electrochem. Soc. 161 (2014) C246-C253.

[14] J. Walton, M.R. Alexander, N. Fairley, P. Roach, A.G. Shard, Film thickness measurement and contamination layer correction for quantitiative XPS. Surf. Interface Anal. 48 (2016) 164-172.

[15] M.A. Jakab, D.A. Little, J.R. Scully, Experimental and modeling studies of the oxygen reduction reaction on AA2024-T3, J. Electrochem. Soc. 152 (2005) B311B320.

[16] D.A. Little, M.A. Jakab, J.R. Scully, Effect of surface pretreatment on the underpaint corrosion of AA2024-T3 at various temperatures, Corrosion 62 (2006) 300-315.

[17] M.B. Vukmirovic, N. Dimitrov, K. Sieradzki, Dealloying and corrosion of Al alloy 2024-T 3, J. Electrochem. Soc. 149 (2002) B428-B439.

[18] A.E. Hughes, G. Theodossiou, S. Elliott, T.G. Harvey, P.R. Miller, J.D. Gorman, P.J.K. Paterson, Study of deoxidation of 2024-T3 with various acids, Mater. Sci. Technol. 17 (2001) 1642-1652.

[19] S.K. Toh, A.E. Hughes, D.G. McCulloch, J. duPlessis, A. Stonham, Characterization of non-Cr-based deoxidizers on Al alloy 7475-T7651, Surf. Interface Anal. 36 (2004) 1523-1532.

[20] A.J. Davenport, B. Liu, Copper accumulation during cleaning of Al-Cu alloys, Proc. Corrosion and Corrosion Prevention of Low Density Metals and Alloys: Proceedings of the International Symposium, Phoenix, Arizona, USA, 2000, The Electrochemical Society, 2001, p. 41. 
[21] S. Adhikari, K.A. Unocic, Y. Zhai, G.S. Frankel, J. Zimmerman, W. Fristad, Hexafluorozirconic acid based surface pretreatments: Characterization and performance assessment, Electrochim. Acta 56 (2011) 1912-1924.

[22] D. Chidambaram, C.R. Clayton, G.P. Halada, The role of hexafluorozirconate in the formation of chromate conversion coatings on aluminum alloys, Electrochim. Acta 51 (2006) 2862-2871.

[23] Y. Liu, F. Colin, P. Skeldon, G.E. Thompson, X. Zhou, H. Habazaki and K. Shimizu, Enrichment factors for copper in aluminium following chemical and electrochemical surface treatments. Corros. Sci. 45 (2003) 1539-1544.

[24] J. Qi, T. Hashimoto, G.E. Thompson, J. Carr, Influence of water immersion posttreatment parameters on trivalent chromium conversion coatings formed on AA2024T351 alloy. J. Electrochem. Soc. 163 (2016) C131-C138.

[25] L.B. Hazell, Quantitative XPS analysis of aluminium in the presence of copper, Surf. Interface Anal. 33 (2002) 791-795.

[26] J.T. Qi, T. Hashimoto, J.R. Walton, X. Zhou, P. Skeldon, G.E. Thompson, Trivalent chromium conversion coating formation on aluminium, Surf. Coat. Technol. 280 (2015) 317-329.

[27] M.C. Biesinger, C. Brown, J.R. Mycroft, R.D. Davidson, N.S. McIntyre, X-ray photoelectron spectroscopy studies of chromium compounds. Surf. Interface Anal. 36 (2004) 1550-1563.

[28] M.C. Biesinger, B.P. Payne, A.P. Grosvenor, L.W.M. Lau, A.R. Gerson, R.S.C. Smart, Resolving surface chemical states in XPS analysis of first row transition metals, oxides and hydroxides: Cr, Mn, Fe, Co and Ni. Appl. Surf. Sci. 257 (2011) 2717-2730. 
[29] A.V. Naumkin, A. Kraut-Vass, S.W. Gaarenstroom, C.J. Powell, NIST X-ray photoelectron spectroscopy database: NIST standard reference database 20, version 4.1. In The Measurement Services Division of the National Institute of Standards and Technology (NIST) Material Measurement Laboratory (MML): Department of Commerce, United of States, (2012).

[30] L.L. Li, D.Y. Kim, G.M. Swain, Transient formation of chromate in trivalent chromium process (TCP) coatings on AA2024 as probed by Raman spectroscopy, J. Electrochem. Soc. 159 (2012) C326-C333.

[31] M. Pourbaix, Altas of Electrochemical Equilibria in Aqueous Solutions, 2nd English ed., National Association of Corrosion Engineers, (1974).

[32] B. Hirschorn, M.E. Orazem, B. Tribollet, V. Vivier, I. Frateur, M. Musiani, Determination of effective capacitance and film thickness from constant-phaseelement parameters, Electrochim. Acta 55 (2010) 6218-6227.

[33] J. Liang, P. B. Srinivasan, C. Blawert, W. Dietzel, Influence of cholride ion concentration on the electrochemical corrosion behaviour of plasma electrolytic oxidation coated AM50 magnesium alloy, Electrochim. Acta 55 (2010) 6802-6811.

[34] L. Li, K.P. Doran, G.M. Swain, Electrochemical characterization of trivalent chromium process (TCP) coatings on aluminum alloys 6061 and 7075, J. Electrochem. Soc. 160 (2013) C396-C401. 


\section{Figure Captions (figures to be in black and white in printed version)}

Figure 1. Scanning electron micrographs of the surface of the AA2024-T351 alloy: (a) pretreatment 1 ; (b) pre-treatment 2.

Figure 2. Scanning electron micrographs for AA2024-T351 following pre-treatment 1 and 2: (a) Al-Cu phase (a, labelled '1') and Al-Cu-Mg phase (a, labelled '2') and (b) Al-Cu-Fe-MnSi phase (labelled '3') after pre-treatment 1. (c) Cu-rich sponge (labelled '4') after pretreatment 2 .

Figure 3. Cyclic voltammetric curve in deaerated borate buffer solution for the AA2024-T351 alloy following mechanical polishing and pre-treatments 1 and 2.

Figure 4. Experimental and simulated (solid line) RBS spectra for the AA2024-T351 alloy following pre-treatment 1 .

Figure 5. Variation of the open circuit potential of the AA2024-T351 alloy, following pretreatments 1 and 2, with immersion time in the SurTec 650 chromitAL bath at $40^{\circ} \mathrm{C}$.

Figure 6. Transmission electron micrographs of ultramicrotomed sections of theAA2024T351 alloy following pre-treatment 2 and subsequent immersion in the SurTec 650 chromitAL bath at $40{ }^{\circ} \mathrm{C}$ for (a) 15 , (b) 60 and (c) $300 \mathrm{~s}$. The specimens were post-treated byimmersion in deionized water at $40{ }^{\circ} \mathrm{C}$. 
Figure 7. Relationship between the coating thicknesses, determined from TEM measurements, and the immersion time in the SurTec 650 chromitAL bath at $40{ }^{\circ} \mathrm{C}$ for the AA2024-T351 alloy following pre-treatments 1 and 2 . The specimens were post-treated by immersion in deionized water at $40{ }^{\circ} \mathrm{C}$.

Figure 8. Experimental RBS spectra for theAA2024-T351 alloy following pre-treatments (PT) 1 and 2 and subsequent immersion in the SurTec 650 chromitAL bath at $40{ }^{\circ} \mathrm{C}$ for $300 \mathrm{~s}$. The specimens were post-treated by immersion in deionized water at $40{ }^{\circ} \mathrm{C}$.

Figure 9. High resolution XPS spectrum for: (a) $\mathrm{Cr} 2 \mathrm{p}_{3 / 2}$; and (b-d) $\mathrm{Zr} 3 \mathrm{~d}$ photoelectron regions for the AA2024-T351 alloy after immersion in the SurTec 650 chromitAL bath at $40{ }^{\circ} \mathrm{C}$ for 300 s. (a, b) Pre-treatment 2 with post-coating immersion in deionized water at $40{ }^{\circ} \mathrm{C}$. (c) Pre-treatment 1 with post-coating immersion in deionized water at $40{ }^{\circ} \mathrm{C}$. (d) Pretreatment 2 with post-coating immersion in deionized water at $20^{\circ} \mathrm{C}$.

Figure 10. Experimental (points) and fitted (lines) plots of (a) impedance modulus-frequency and (b) phase angle-frequency for the AA2024-T351 alloy immersed in $0.05 \mathrm{M} \mathrm{NaCl}$ solution. The alloy first received pre-treatments 1 or 2 and was then immersed in the SurTec 650 chromitAL bath at $40{ }^{\circ} \mathrm{C}$ for $300 \mathrm{~s}$ and post-treated by immersion in deionized water at $40{ }^{\circ} \mathrm{C}$.

Figure 11. Equivalent circuit used to fit EIS data.

Figure 12. Potentiodynamic polarization curves in $0.05 \mathrm{M} \mathrm{NaCl}$ solution for of the AA2024T351 alloy following pre-treatments 1 and 2 and also following subsequent immersion in the 
SurTec 650 chromitAL bath at $40{ }^{\circ} \mathrm{C}$ for $300 \mathrm{~s}$ and post-treatment immersion in deionized water at $40{ }^{\circ} \mathrm{C}$. 
Table 1. Results of EDX analyses of residual intermetallic particles following pre-treatment 1.

\begin{tabular}{cccccccc}
\hline & $\mathrm{Al}$ & $\mathrm{Cu}$ & $\mathrm{Mg}$ & $\mathrm{Fe}$ & $\mathrm{Mn}$ & $\mathrm{Si}$ & $\mathrm{O}$ \\
\hline & & & \multicolumn{7}{c}{ (wt.\%) } \\
\hline $\mathrm{Al}-\mathrm{Cu}(\theta)(1)$ & 45.1 & 53.1 & 0.8 & - & - & - & 1.0 \\
$\mathrm{Al}-\mathrm{Cu}-\mathrm{Mg}(\mathrm{S})(2)$ & 41.9 & 42.4 & 14.2 & - & - & - & 1.5 \\
$\mathrm{Al}-\mathrm{Cu}-\mathrm{Fe}-\mathrm{Mn}-\mathrm{Si}(3)$ & 54.1 & 20.8 & - & 15.4 & 7.3 & 1.4 & 1.0 \\
\hline
\end{tabular}

Table 2. Amounts of zirconium and chromium determined by RBS in TCC coatings formed for 60 and 300 s following pre-treatments (PT) 1 and 2, and post-treatment immersion in deionized water at $40{ }^{\circ} \mathrm{C}$.

\begin{tabular}{cccc|c}
\hline & & $\mathrm{Zr}$ & $\mathrm{Cr}$ & $\mathrm{Cr} / \mathrm{Zr}$ \\
\hline & \multicolumn{3}{c}{$\begin{array}{c}\text { x 10 } \\
\mathrm{cm}^{-2}\end{array}$} \\
\hline \multirow{2}{*}{ PT 1 } & $60 \mathrm{~s}$ & 11.0 & 10.2 & $0.93 \pm 0.06$ \\
& $300 \mathrm{~s}$ & 33.6 & 26.3 & $0.78 \pm 0.05$ \\
& $60 \mathrm{~s}$ & 14.7 & 10.8 & $0.73 \pm 0.06$ \\
PT 2 & $300 \mathrm{~s}$ & 25.5 & 19.9 & $0.78 \pm 0.05$ \\
\hline
\end{tabular}

Table 3. Elemental concentrations determined by XPS of TCC coatings formed for $300 \mathrm{~s}$ following pre-treatments (PT) 1 and 2, and post-treatment immersion in deionized water at $40{ }^{\circ} \mathrm{C}$.

\begin{tabular}{cccccccc}
\hline & $\mathrm{Zr}$ & $\mathrm{Cr}$ & $\mathrm{O}$ & $\mathrm{F}$ & $\mathrm{S}$ & $\mathrm{Cu}$ & $\mathrm{Al}$ \\
\hline PT 1 & 8.8 & 10.2 & 58.9 & 13.8 & 1.2 & 0.3 & 6.8 \\
PT 2 & 8.6 & 10.6 & 58.8 & 12.0 & 1.4 & 1.0 & 7.6 \\
\hline
\end{tabular}


Table 4. Results of EIS for the alloy in $0.05 \mathrm{M} \mathrm{NaCl}$ solution following pre-treatments (PT) 1 and 2 and subsequent formation of a conversion coating for $300 \mathrm{~s}$. and post-treatment immersion in deionized water at $40{ }^{\circ} \mathrm{C}$.

\begin{tabular}{|c|c|c|c|c|c|c|c|c|}
\hline & $\begin{array}{c}\mathrm{R}_{\mathrm{e}} \\
\Omega \mathrm{cm}^{2}\end{array}$ & $\begin{array}{c}\mathrm{R}_{\text {coat }} \\
\mathrm{k} \Omega \mathrm{cm}^{2}\end{array}$ & $\begin{array}{c}\mathrm{R}_{\mathrm{p}} \\
\mathrm{k} \Omega \mathrm{cm}^{2}\end{array}$ & $\begin{array}{c}\mathrm{Q}_{\text {coat }} \\
\left(\mathrm{s}^{\mathrm{n}} /\left(\Omega \mathrm{cm}^{2}\right)\right)\end{array}$ & $\mathrm{n}_{\text {coat }}$ & $\begin{array}{c}\mathrm{C}_{\text {eff-co }} \\
\mu \mathrm{F} / \mathrm{cm}^{2}\end{array}$ & $\begin{array}{c}\text { Qdl } \\
\left(\mathrm{s}^{\mathrm{n}} /\left(\Omega \mathrm{cm}^{2}\right)\right)\end{array}$ & $\mathrm{n}_{\mathrm{dl}}$ \\
\hline PT 1 & $153 \pm 2$ & $0.41 \pm 0.01$ & $68.2 \pm 0.8$ & $1.4 \pm 0.4 \times 10^{-5}$ & $0.80 \pm 0.01$ & $3.0 \pm 0.1$ & $2.1 \pm 0.4 \times 10^{-6}$ & $0.99 \pm 0.02$ \\
\hline PT 2 & $170 \pm 5$ & $8.23 \pm 0.12$ & $203.2 \pm 1.2$ & $8.9 \pm 0.3 \times 10^{-6}$ & $0.83 \pm 0.01$ & $2.4 \pm 0.2$ & $2.8 \pm 0.4 \times 10^{-6}$ & $0.96 \pm 0.02$ \\
\hline
\end{tabular}



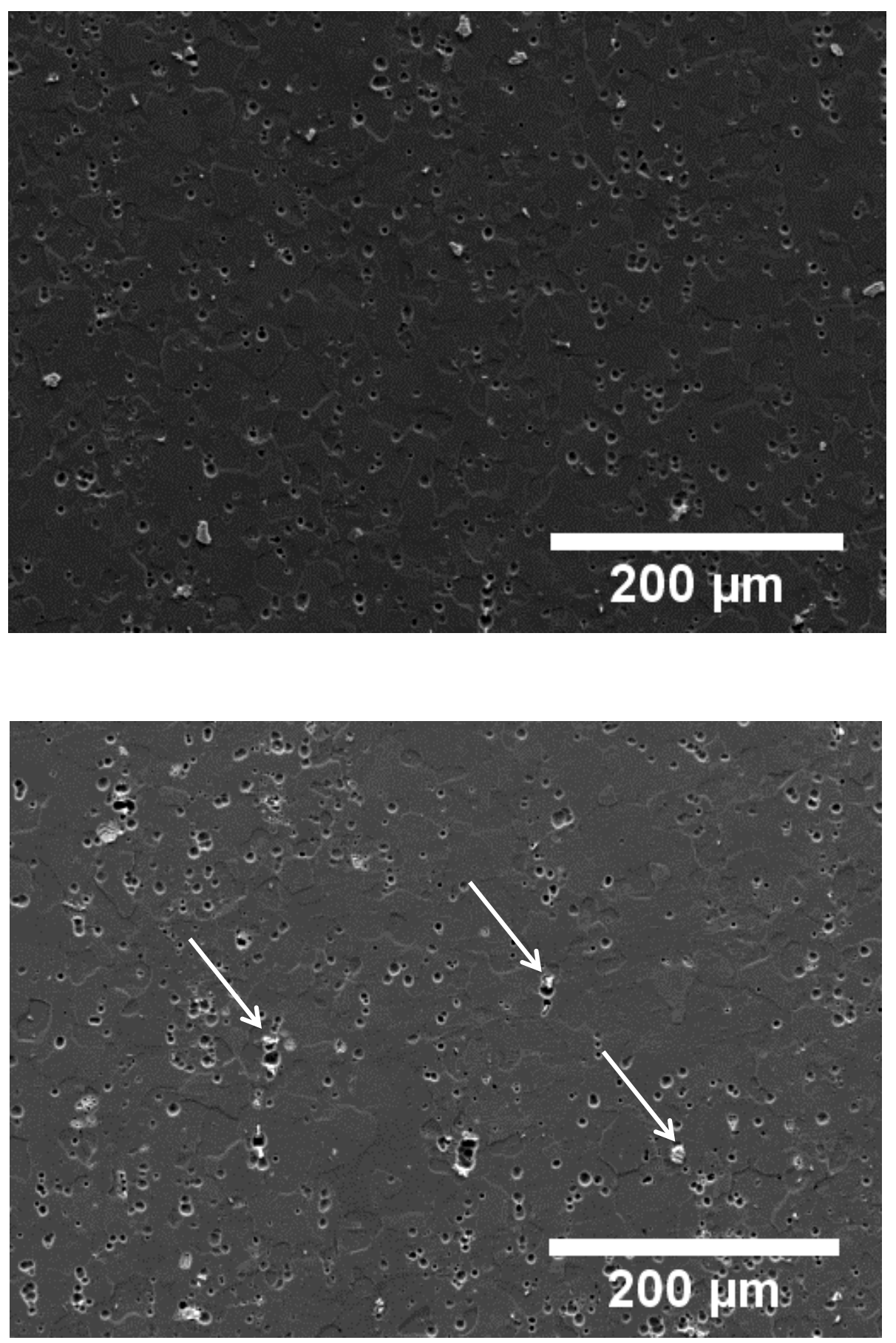

Figure 1 


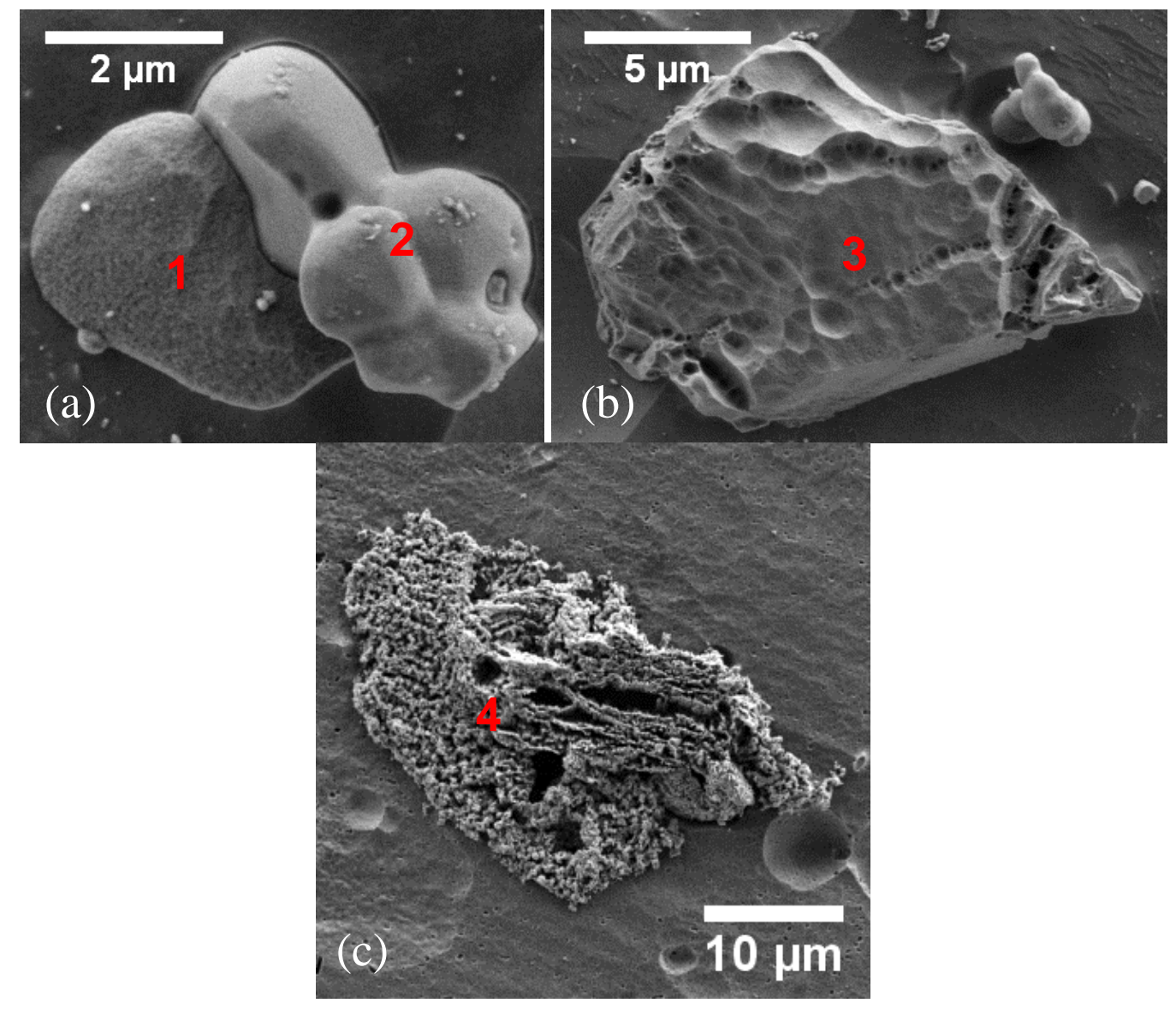

Figure 2 


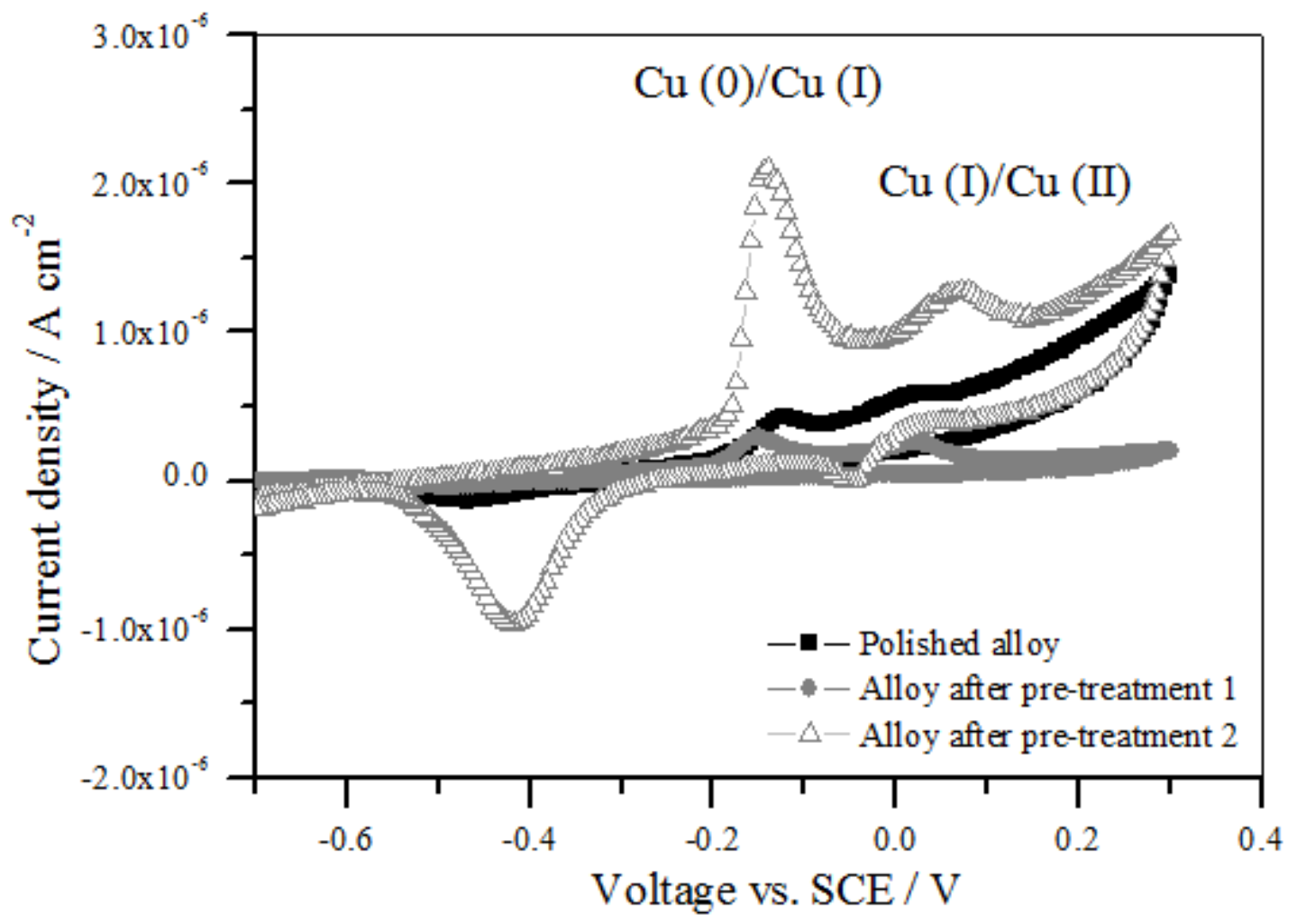

Figure 3 


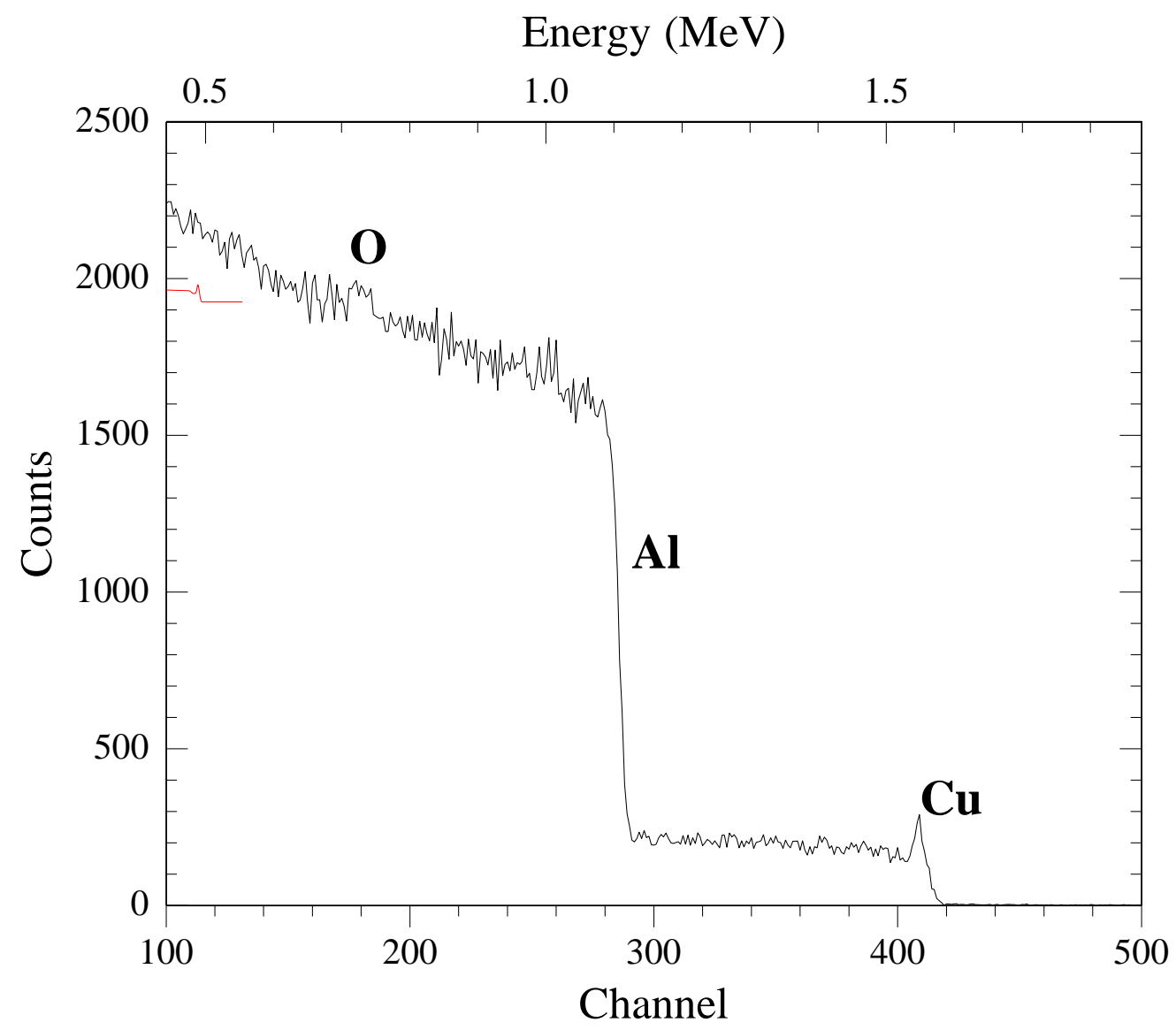

Figure 4 


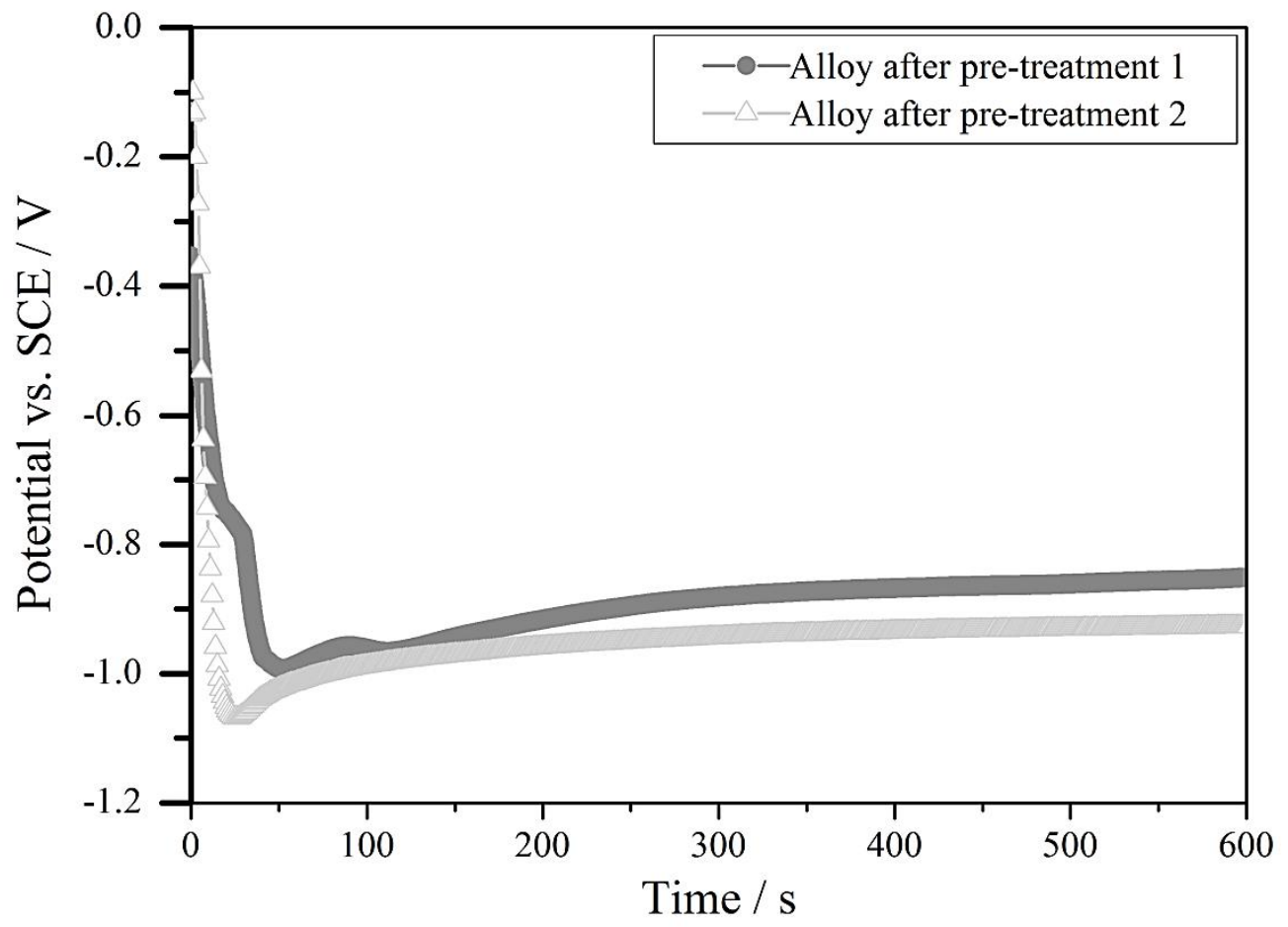

Figure 5 

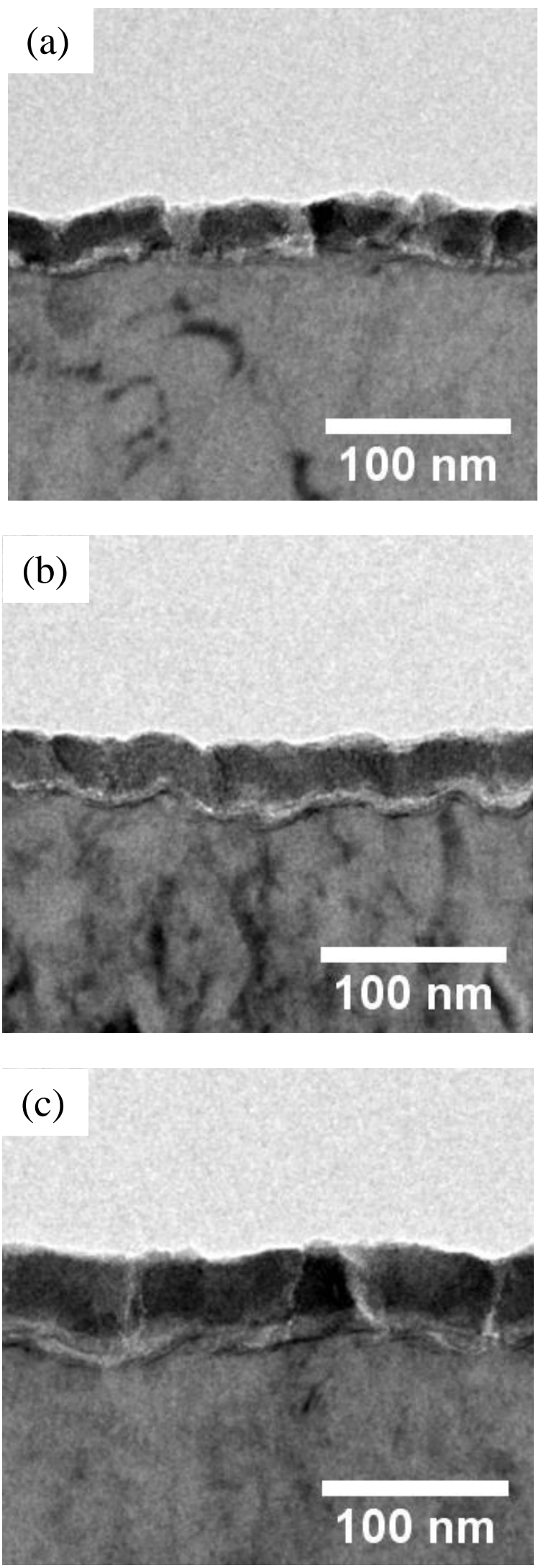

Figure 6 


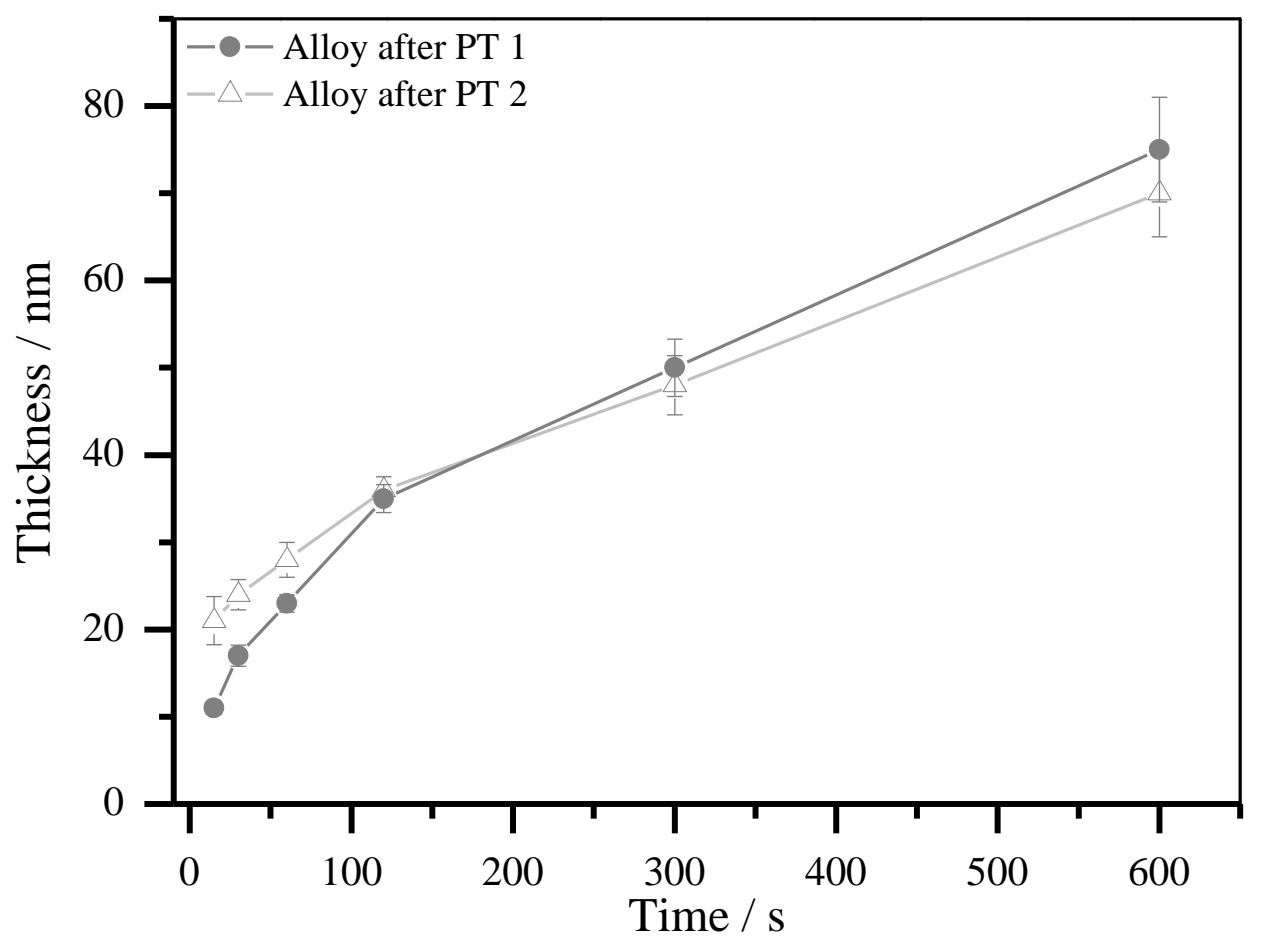

Figure 7 


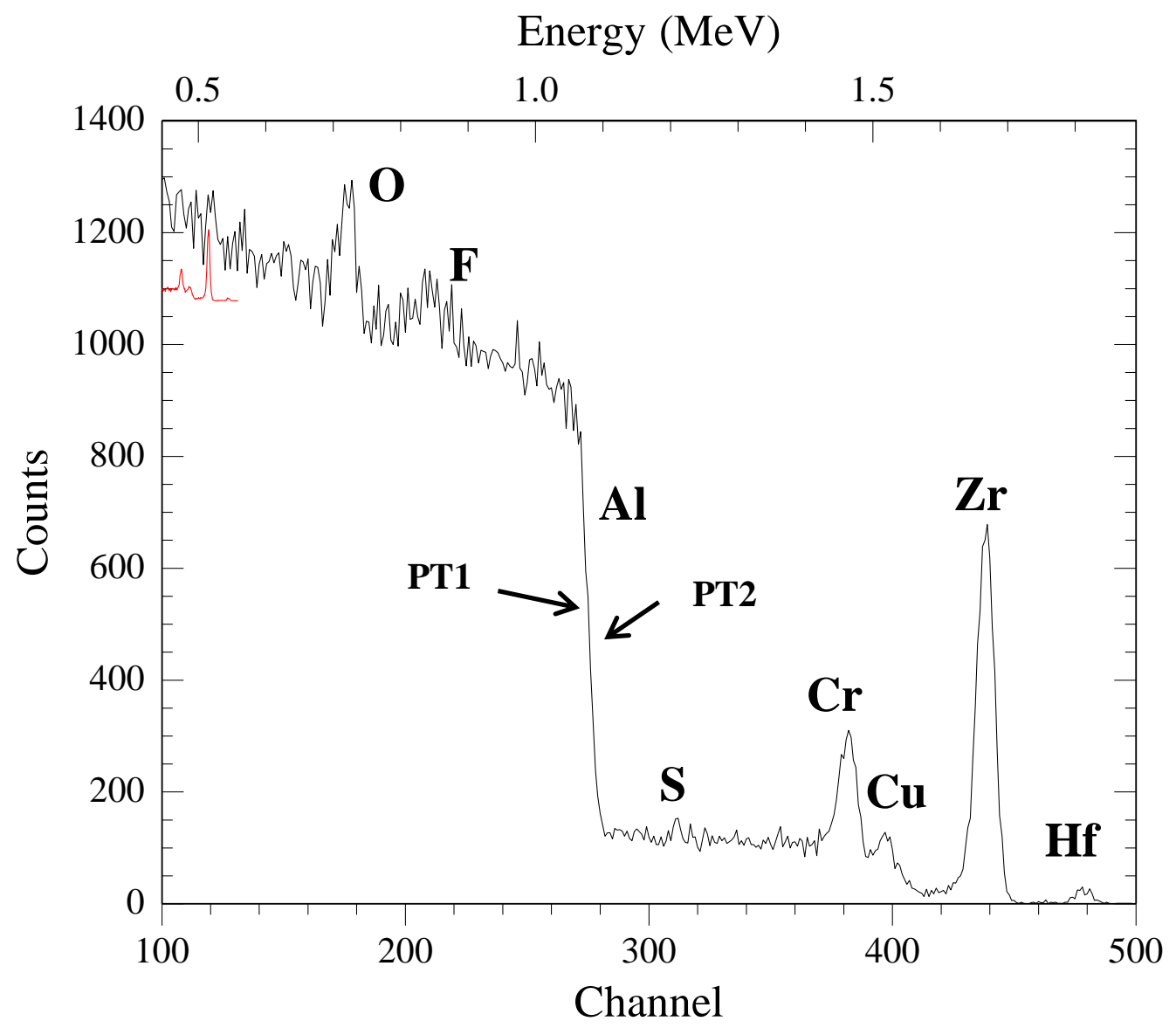

Figure 8 

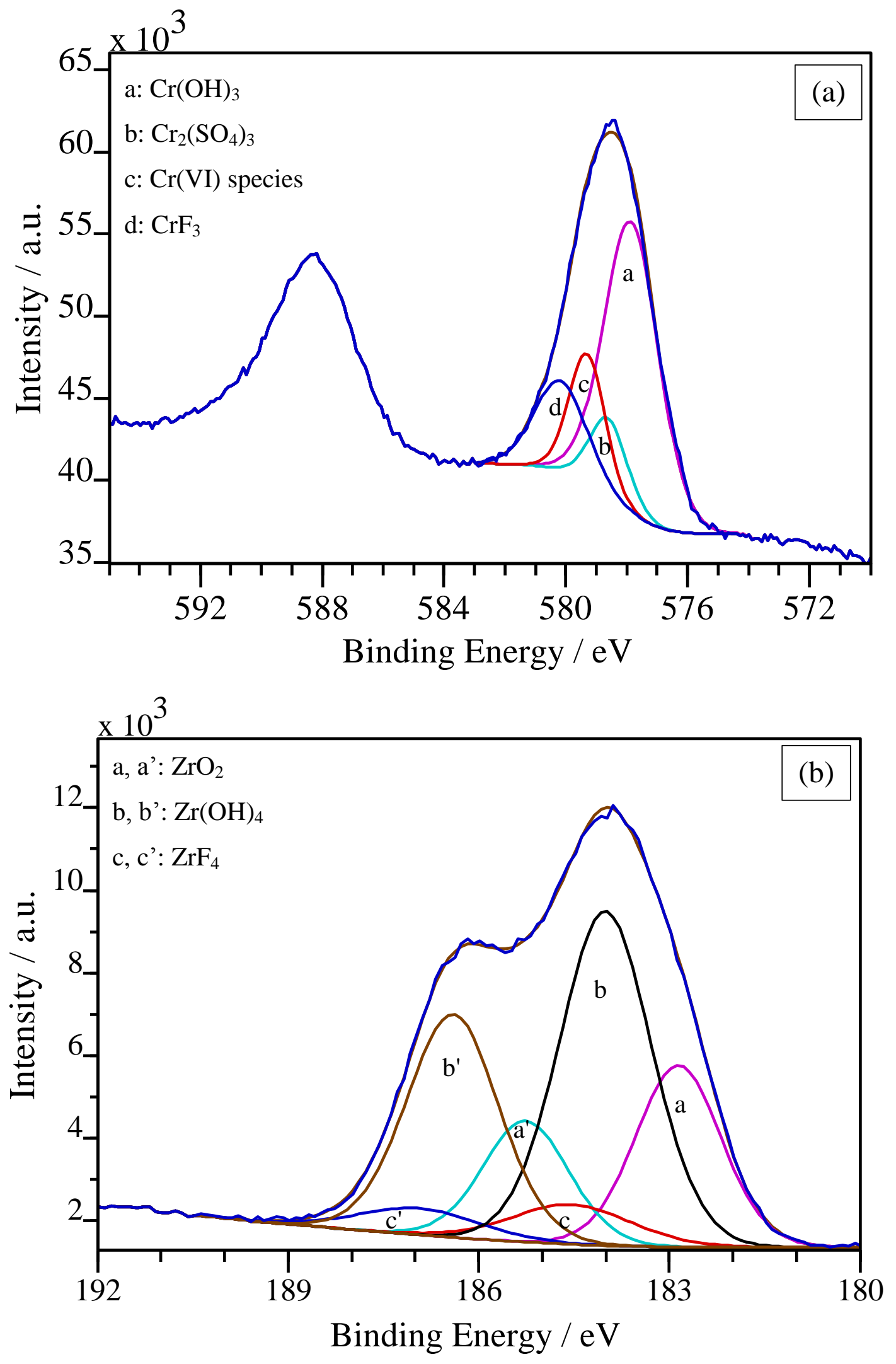

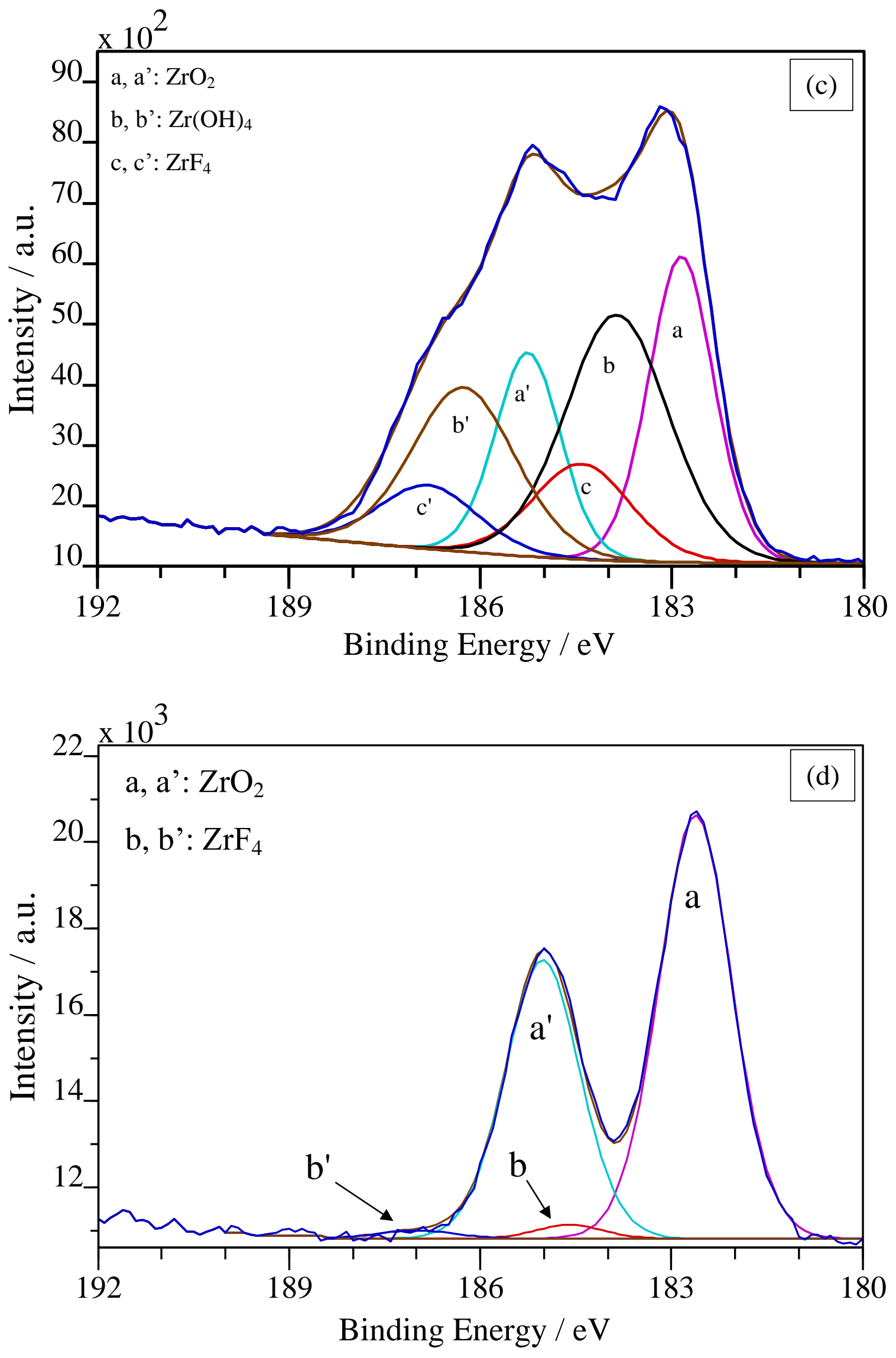

Figure 9 

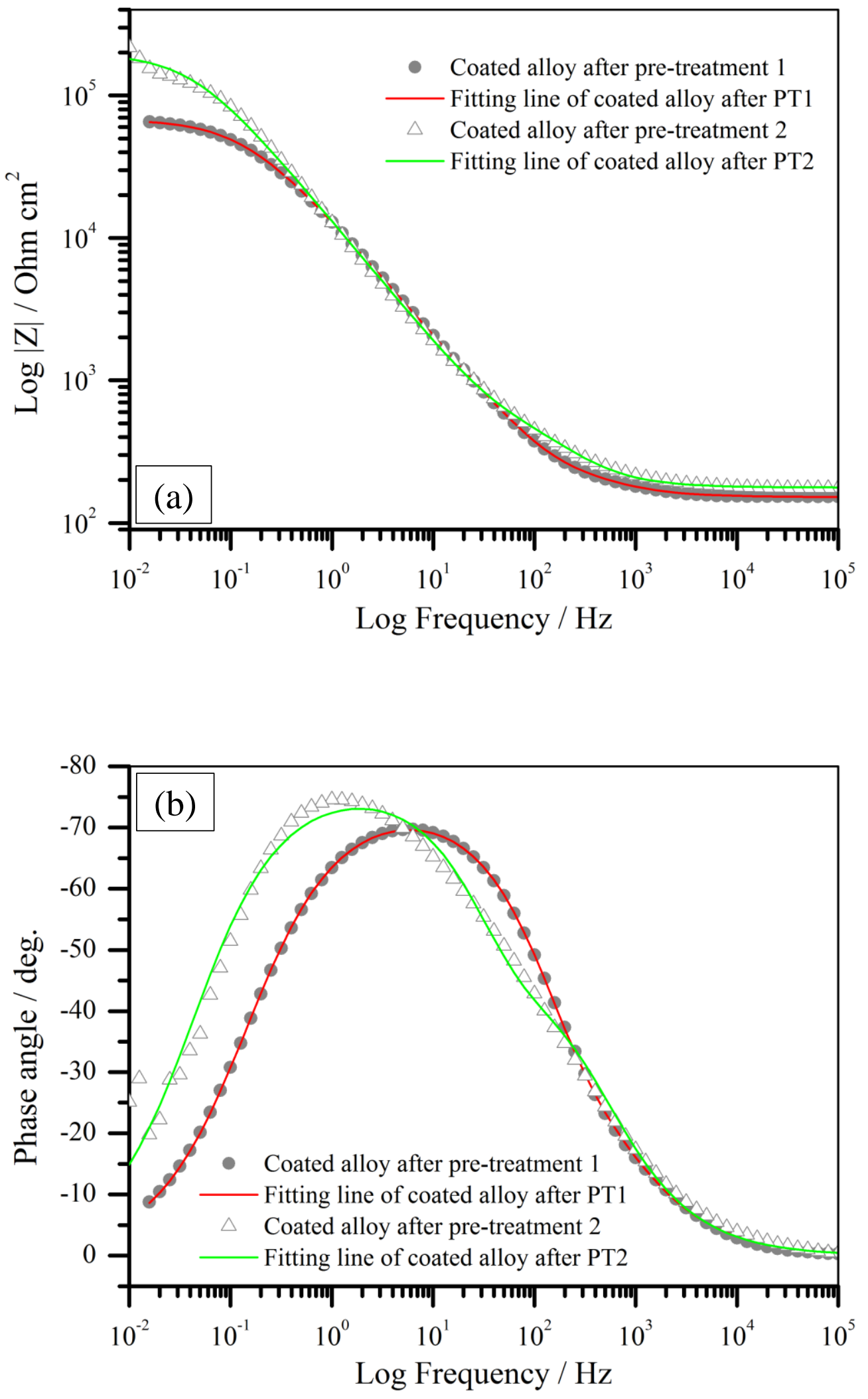

Figure 10 


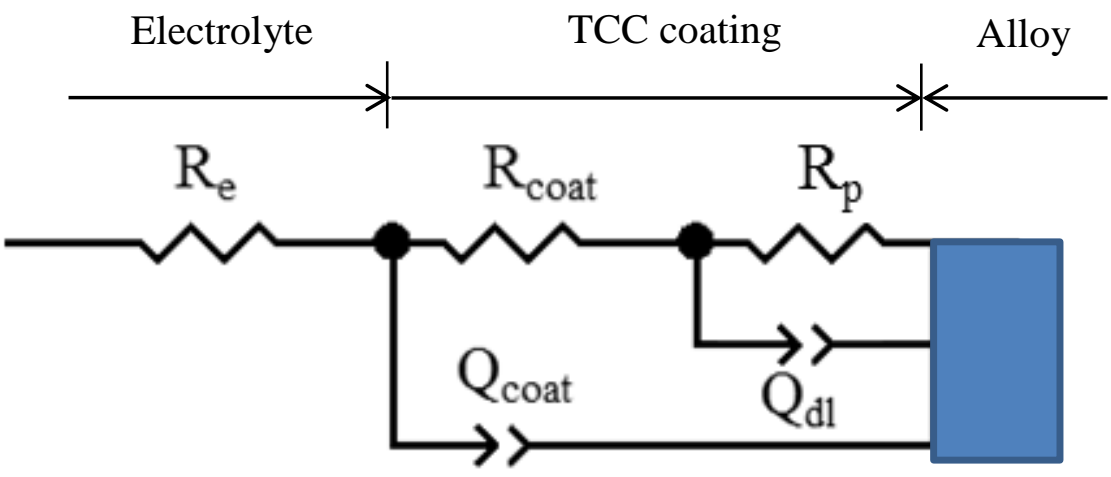

Figure 11 


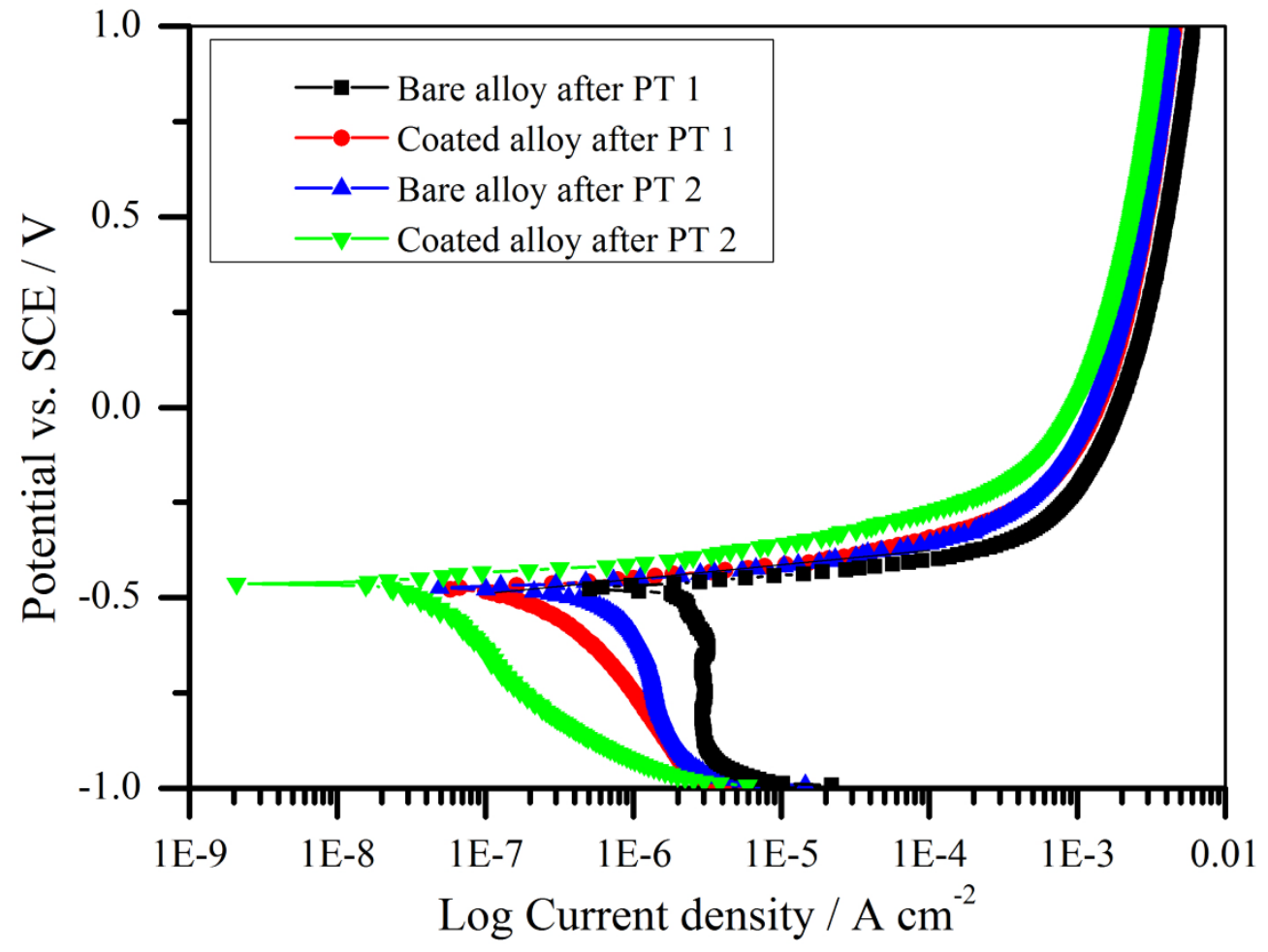

Figure 12 